Review

\title{
Interleukin-6, a Major Cytokine in the Central Nervous System
}

\author{
María Erta ${ }^{1}$, Albert Quintana ${ }^{2}$, and Juan Hidalgo ${ }^{1 凶}$ \\ 1. Instituto de Neurociencias y Departamento de Biología Celular, Fisiología e Inmunología, Facultad de Biociencias, Uni- \\ versitat Autònoma de Barcelona, Barcelona, Spain. \\ 2. Howard Hughes Medical Institute and Department of Biochemistry, University of Washington, WA, USA.
}

$\triangle$ Corresponding author: Dr. Juan Hidalgo, Departamento de Biología Celular, Fisiología e Inmunología, Unidad de Fisiología Animal, Facultad de Biociencias, Universitat Autònoma de Barcelona, Bellaterra, Barcelona, Spain 08193. Tel. 3493 581 2037 ; fax: 34 9358123 90; email: Juan.Hidalgo@uab.es.

(c) Ivyspring International Publisher. This is an open-access article distributed under the terms of the Creative Commons License (http://creativecommons.org/ licenses/by-nc-nd/3.0/). Reproduction is permitted for personal, noncommercial use, provided that the article is in whole, unmodified, and properly cited.

Received: 2012.06.01; Accepted: 2012.07.19; Published: 2012.10.25

\begin{abstract}
Interleukin-6 (IL-6) is a cytokine originally identified almost 30 years ago as a B-cell differentiation factor, capable of inducing the maturation of B cells into antibody-producing cells. As with many other cytokines, it was soon realized that IL-6 was not a factor only involved in the immune response, but with many critical roles in major physiological systems including the nervous system. IL-6 is now known to participate in neurogenesis (influencing both neurons and glial cells), and in the response of mature neurons and glial cells in normal conditions and following a wide arrange of injury models. In many respects, IL-6 behaves in a neurotrophin-like fashion, and seemingly makes understandable why the cytokine family that it belongs to is known as neuropoietins. Its expression is affected in several of the main brain diseases, and animal models strongly suggest that IL-6 could have a role in the observed neuropathology and that therefore it is a clear target of strategic therapies.
\end{abstract}

Key words: Neuropoietin, Neuroinflammation, Neurogenesis, Gliogenesis, Alzheimer's disease, Multiple Sclerosis, Stroke, Trauma.

\section{Interleukin-6, the founding member of the neuropoietins}

Cytokines are small proteins initially thought to be components of the immune system, but have since been found to play a much broader role in physiology. Interleukin-6 (IL-6) is a cytokine originally identified as a B-cell differentiation factor (BSF-2) in 1985 [1], as a factor that induced the maturation of $B$ cells into antibody-producing cells. Human IL-6 [2] and IL-6 receptor [3] were cloned soon thereafter. As with many other cytokines, it was soon realized that IL-6 was not a factor only involved in the immune response. In early 1990s it was clear that besides controlling other immune cells such as T cells, IL-6 was also important in the regulation of hepatocytes, hematopoietic progenitor cells, the skeleton, the cardio- vascular system, the placenta and the nervous and endocrine systems [4].

The number of cytokines known nowadays is enormous. Structural analysis has allowed the grouping of these proteins into different structural classes such as the helical cytokines, the trimeric tumor necrosis factor (TNF) family, the cysteine knot growth factors and the $\beta$-trefoil growth factors [5]. Cytokines can also be grouped according to the type of receptor they bind, which comprise six major families: class I cytokine receptors (the largest family), class II cytokine receptors, TNF receptors, tyrosine kinase receptors, and chemokine receptors [5]. Cytokine families may be named differently according to other aspects such as the sharing of a receptor subunit (i.e. the gp130 family) or its physiological roles (i.e. 
neuropoietic family, for its effects on hematopoietic and nervous system).

IL-6 is a prototypical four-helix bundle cytokine that is the founder member of the neuropoietins, a group of cytokines structurally related, that include IL-6, IL-11, IL-27, IL-31, leukemia inhibitory factor, oncostatin $\mathrm{M}$, cardiotrophin-1, neuropoietin and cytokine cardiotrophin-like (also known as new neurotrophin 1 and B cell stimulatory factor-3), and two viral analogs of IL-6 [5-10]. These cytokines bind to class I cytokine receptors, membrane proteins with a characteristic modular architecture that do not have intrinsic enzymatic activity, and that for signaling often need to recruit additional receptor proteins shared by different cytokines: gp130, $\beta c$ or $\gamma c$. The IL-6 family of cytokines recruits gp130 for signaling (Figure 1). Thus, the family is also known as the gp130 family of cytokines. This protein has also a modular architecture, part of which has features typical of the cytokine receptors (two fibronectin type III modules containing conserved cysteine residues and a WSXWS motif) [4]. For IL-6 specifically, a hexamer forms (two IL-6, two IL-6R and two gp130) that can activate intracellular tyrosin-kinases such as Janus kinase (JAK) and, to a lesser extent, TYK, which, in turn, activate a number of proteins including the STAT (signal transducer and activator of transcription) family of transcription factors, or the RAS-RAF-MAPK pathway, PI3 (phosphatidyl inositol-3) kinase, or IRS (insulin receptor substrate) [11]. The sharing of gp130 explains at least in part the redundancy of the actions of these cytokines.

It was soon established that the expression of IL-6R is restricted to some tissues, while that of gp130 is ubiquitous, and that IL-6 may upregulate gp130 expression [12]. The same study already provided evidence that extracellular, soluble IL-6R (sIL-6R) in the presence of IL-6 could activate cells expressing gp130, and stated that naturally occurring sIL-6R could be found in the murine serum. It is now widely accepted that sIL-6R is formed physiologically, either by limited proteolysis of the extracellular domain of membrane IL-6R (mIL-6R) by metalloproteases such as ADAM10 and ADAM17, or by alternative splicing of IL-6R mRNA, and that sIL-6R can bind both IL-6 and gp130 and signal in cells with or without endogenous IL-6R expression, a mechanism known as trans-signaling [13]. To complicate things further, it is also known that a soluble form of gp130 (sgp130) is also formed [14], in this case only by alternative splicing of gp130 mRNA; sgp130 can inhibit trans-signaling but does not affect normal signaling by mIL-6R (Figure 1).

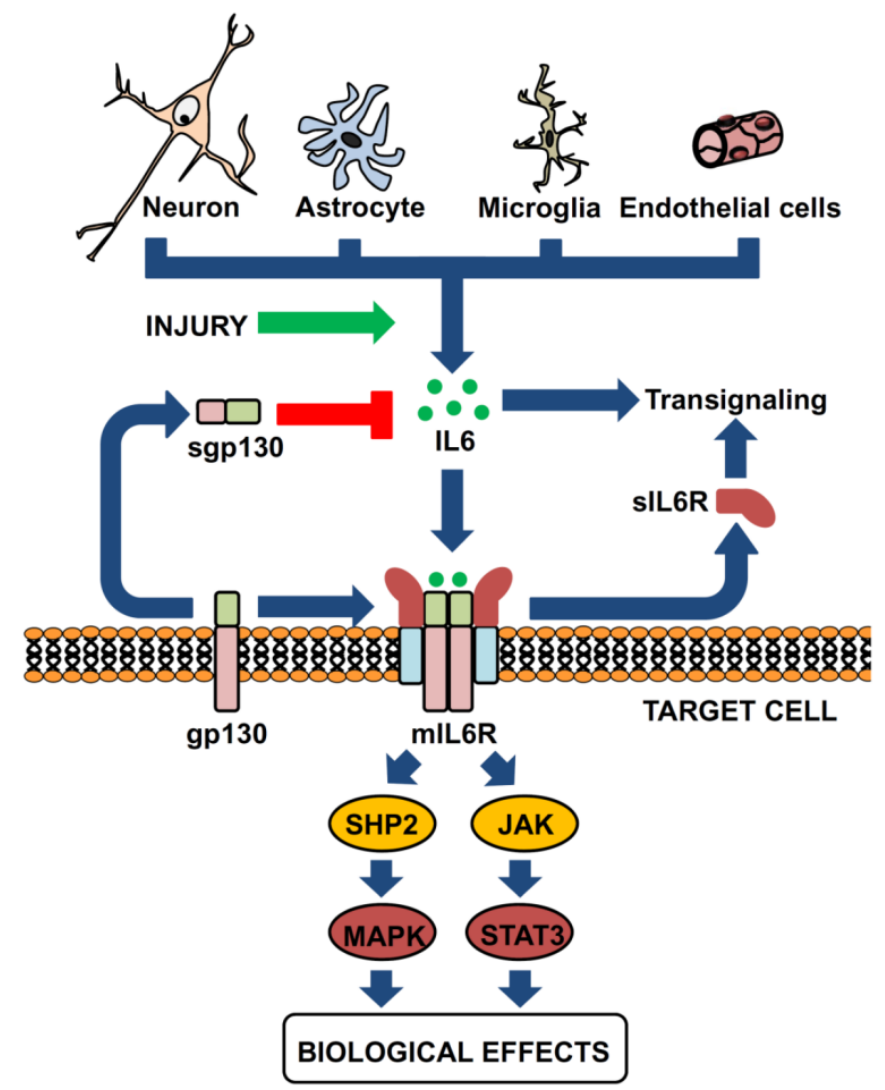

Figure I. IL-6 is produced by different brain cells and may signal in a complex manner. Neurons, astrocytes, microglia and endothelial cells the essential sources of IL- 6 in the CNS. All of them may produce some amounts of IL-6, but upon proper stimuli such as injury copious amounts of IL- 6 will be secreted. IL- 6 can bind to the membrane-bound IL-6 receptor ( $\mathrm{mlL}-6 \mathrm{R}$, expressed in limited cells) or to the soluble form of the receptor (sIL-6R), which is known as trans-signaling; both of them can properly signal upon interaction with the sgpl30 protein (expressed ubiquitously). A releasable form of gpl 30 can also be found in biological fluids, which will exert inhibitory actions on trans-signaling.

\section{Interleukin- 6 expression in the central nervous system}

Soon after its discovery, it was demonstrated that some astrocytoma and glioma lines expressed IL-6 when stimulated with IL-1 $\beta$, which prompted speculation that IL-6 could have a role in the CNS [2]. The same group demonstrated that IL- 6 indeed was capable of inducing the neuronal differentiation of the rat pheochromocytoma PC12 cell line, to some extent similarly to the prototypical neurotrophin NGF [15, 16]. It was therefore not surprising the finding that both glial and neuronal cells expressed IL-6 and IL-6R to various degrees throughout the brain [17-24]. In vitro, microglia, astrocytes and the neuronal line N18, but not oligodendrocytes, expressed IL-6R [25]; in vivo, nevertheless, oligodendrocytes may express IL-6 and IL-6R [26]. Also, IL-6 and IL-6R were expressed in sympathetic and sensory ganglia, predominantly in neurons [27], as well as in adrenal chromaffin cells 
[28], of adult rats. In line with these results, in vitro studies demonstrated that dissociated sympathetic neurons and PC12 cells expressed IL- 6 and the two receptors, IL-6R and gp130 [29, 30]. Besides neurons and glial cells, endothelial cells produce copious amounts of IL-6, which can act on surrounding cells but also in an autocrine manner regulating a number of adhesion proteins but also IL-6 synthesis, particularly in the presence of sIL-6R [31-33]. Thus, both the central and the peripheral nervous system appear to express IL-6 and the corresponding receptors (Figure $1)$.

Many cytokines and inflammatory factors as well as neurotranmitters and neuropeptides have been shown to affect IL-6 regulation in brain cells; we will comment here some of them studied in in vitro assays. Both virus-infected microglial cells and astrocytes secreted IL-6 $[34,35]$. IL-1 $\beta$ and TNFa induced IL-6 in cultured cortical neurons [36] and astrocytes $[37,38]$, in the latter involving NFKB [39] and the PKC pathway [40]. The AMPc-PKA pathway may also induce astrocytic IL-6 [40-42]. It is likely that membrane depolarization is one of the main mechanisms for neuronal upregulation of IL-6, where $\mathrm{Ca}^{2+}$ currents (such as those elicited by the glutamate agonist NMDA) and $\mathrm{Ca}^{2+}$ /calmodulin-dependent kinases are critical factors $[43,44]$. The major bacterial pathogen, LPS, normally induces IL- 6 in both astrocytes and microglia [45-47], but TNF- $\alpha$ induces IL-6 in astrocytes but not microglia [45]. There may be species-specific effects since in human cells in vitro LPS mostly affect microglia rather than astrocytes (obtained from brains at second trimester of gestation) regarding TNFa, IL-1 $\beta$ and IL-6 production, although IL-1 $\beta$ is a potent stimulator of IL-6 production in astrocytes (in microglia the 3 cytokines are upregulated) $[46,48]$. GM-CSF stimulates microglial IL-6 but not that of astrocyte [49], whereas IFN- $\gamma$ induces IL-6 (and $\mathrm{NO}$ ) in the murine microglial cell line 6-3 [50]; this cytokine does not induce IL-6 in astrocytes unless it is coincubated with IL-1 $\beta$ [37]. Interestingly, adult human astrocyte cultures subjected to mechanical injury upregulated IL-6 [51]. IL-6 production by astrocytes is subjected to autocrine regulation by IL-6, and the addition of sIL-6R synergizes dramatically with IL-1 $\beta$ and TNFa to induce IL-6 [52]. Oncostatin M (OSM) induced IL-6 alone and synergized with TNFa to induce IL-6 [52]. IL-17 functioned in a synergistic manner with IL-6 (+ sIL-6R) to induce IL-6 expression in astrocytes [53].

Norepinephrine, vasoactive intestinal peptide (VIP) and pituitary adenylate cyclase activating polypeptide (PACAP38) stimulate IL-6 in astrocytes, and may synergize with IL-1 $\beta$ and TNFa [54-56]; in con- trast any of these factors have a major effect in microglia [54]. VIP may induce IL-6 through the PKA pathway and independently of prostaglandins [57, 58]. Prostaglandin E1 (PGE1) and PGE2, but not PGD2 and PGF2 alphaE2, induce IL-6 in human astrocytoma cells; PGE2 potentiates IL-1 $\beta$ induction of IL-6 $[59,60]$. The synthetic ceramides C2- and C6-ceramide as well as the enzyme sphingomyelinase were able to induce IL-6 in astrocytes [61]. IL-1 $\beta$, substance $P$ and histamine induced IL-6 expression in human astrocytoma cells $[41,62]$, through NF-kB for IL-1 $\beta$ and through NF-IL-6 for SP and histamine [63]. Bradykinin stimulates IL-6 expression through activation of NF- $\mathrm{KB}$ in murine astrocytes [64]. Serotonin and adenosine agonists were also effective inducers in human astrocytoma cells [65] [66]; in mouse astrocytes, adenosine induces IL-6 through activation of PKA and NF-IL-6 [67]. TGF- $\beta$ inhibits microglia proliferation and activation, including IL-6 production [68]; in contrast, it stimulates IL-6 production in astrocytes [69].

\section{Role of interleukin-6 in development and normal physiology}

IL-6 may affect neuronal functionality, for instance it induces the cholinergic phenotype of sympathetic neurons [30, 70, 71]. Sensory neurons are particularly affected by IL-6 deficiency, since in normal conditions IL-6 KO mice show a $60 \%$ reduction of the compound action potential of the sensory branch of the sciatic nerve and a dramatic decrease of temperature sensitivity in the frontpaw withdrawal time in the hot-plate assay [72]; these neurons are also highly dependent on IL-6 for functional recovery following injury $[72,73]$. Results with IL-6 KO mice imply a role for IL-6 on sympathetic sprouting induced by nerve injury [74, 75]. It also promotes sprouting and functional recovery of organotypical cultures of hippocampus [76], and causes a dose-dependent decrease of post-tetanic potentiation (PTP) and long-term potentiation (LTP) in the CA1 region of rat hippocampus [77].

IL-6 also has a notorious role in adult neurogenesis $[10,78]$, the process of creating new neurons and glial cells from neural stem cells (NSCs) discovered almost 50 years ago [79], which is now known to be dramatically affected by a myriad of factors such as exercise, environmental enrichment, stress, or aging. Not surprisingly, neurogenesis is also altered in many neuropathological situations like stroke, status epilepticus, mechanical damage, and Alzheimer, Parkinson and Huntington diseases; in all these cases a detrimental role of inflammation has usually been suggested [80, 81], and, as stated above, IL-6 will be upregulated and could have a role on neurogenesis. 
GFAP-IL6 mice, indeed, show a diminished hippocampal neurogenesis [82], and moreover, in vitro IL-6 clearly decreases the differentiation of neural stem/progenitor cells into neurons [83, 84]. In contrast, IL-6 is involved in oligodendrogliogenesis [85, 86] and astrogliogenesis [84]. Yet, other studies claimed that IL-6 promotes both gliogenesis (through the STAT-3 pathway) and neurogenesis (MAPK/CREB pathway) $[87,88]$.

Besides effects on neurons, IL-6 also displays a number of effects in glial and endothelial cells. Early in vitro assays showed that both virus-infected microglia and astrocytes secreted IL6, and that IL-6 induced the secretion of the major neurotrophin NGF by the latter [34]. In vitro there is some conflicting results whether or not IL-6 does have proliferative effects on astrocytes [89, 90], probably it does but synergizing with other factors [91]. Microglia in culture consistently proliferate when stimulated with IL-6 [92]IL-6-IL-6/sIL-6R may alter the factors produced by astrocytes: for instance it induces specific patterns of neurotrophins [93], inhibits TNFa [94], and together with sIL-6R and IL-17, it may shift chemokine production to that favoring $\mathrm{T}$ cell recruitment to the CNS [95]. Differences in the pattern of cytokines secreted by astrocytes of IL-6 KO mice are readily noticeable in vitro [96]. In vivo experiments demonstrate that IL-6 exerts profound effects on their differentiation, which is dependent on the brain area from which they are isolated [93]. Transgenic mice overexpressing IL-6 show prominent astrogliosis and microgliosis [97-100], whereas the opposite is usually observed in IL-6 KO mice in different models of injury [101-105]. IL-6 alone does not affect intercellular adhesion molecule-1 (ICAM-1) gene expression, but dramatically inhibits the activating effect of IFN- $\gamma$, IL-1 $\beta$ and TNFa in rat astrocytes, and that of IFN- $\gamma$ in microglia, very much alike IL-10 [106]. In human astrocytes, IL-6, sIL-6R or both do not affect VCAM-1 or ICAM-1, but IL-6/sIL-6R complex (and H-IL-6) inhibits TNF-a-induced VCAM-1 gene expression; sIL-6R upregulates endogenous IL-6 production [107]. This inhibitory effect of IL-6 in astrocytes is in sharp contrast with the stimulatory effect it has on endothelial cells, where again sIL-6R greatly affects the activation of endothelial cells, not only upregulating the adhesion proteins E-selectin, ICAM-1 and VCAM-1 but also IL-6, IL-8 and monocyte chemotactic protein 1 (MCP-1); this constitutes a model where neutrophils may retrogradely signal inflammation to endothelial cells by shedding sIL-6R, which can then recruit leukocytes and contribute to their extravasation [32, 108]. Regarding oligodendrocytes, in addition to promoting oligondendrogenesis IL-6 promotes survival and myelin production of oligodendrocytes $[85,86,109$, 110].

Although IL-6 is often related to inflammatory and pathological situations, it is a factor that contributes decisively in the normal function of the brain. Thus, IL-6 is involved in the control of body weight, food intake and energy expenditure [111-115], stimulates the pituitary-adrenal axis [116] [117], induces fever $[111,118,119]$ and is for instance very important in the control of body temperature following recovery from stroke [120]. Results with IL-6 KO mice imply a facilitatory role for IL-6 in pain [74, 75], effects on sleep-wake beavior [121], emotional reactivity [122, 123], sickness behaviour [124] and learning and memory [125-127].

\section{Dual role of interleukin-6 in injury/disease}

As stated above, soon after its discovery IL-6 was shown to induce the neuronal differentiation of PC12 cells $[15,16]$. After these initial studies, a flurry of papers demonstrated that IL-6 affected in many different ways neurons and glial cells. Thus, it was shown to promote the survival of cultured basal forebrain and septal cholinergic neurons and mesencephalic catecholaminergic neurons [128, 129], retinal ganglion cells [130], sympathetic neurons and dorsal root ganglia (DRG), particularly if sIL-6R was added to the culture $[30,131]$. It has been suggested that a survival mechanism could be the inhibition of neuronal activity and release of glutamate [132].

In vivo, the role of IL-6 on survival depends on the type of neuron. IL-6 increases with development in DRG, but levels are low in adults; however, following sciatic nerve transection its expression increases dramatically, not only in the DRG but also in many neurons in the corresponding motor nucleus or sympathetic ganglion [133]. Studies in a drop weight model of cortex lesion (closed skull) also indicate that IL-6 expression increases following axonal damage, mainly in neurons [134], thus probably neuronal induction of IL-6 in response to injury is a general response. In the sciatic model, IL-6 expression increases potently within large and medium-sized axotomized neurons [133], whose survival is decreased by $50 \%$ in IL-6 KO mice [135]. IL-6 probably promotes survival through inducing BDNF, and indeed in vivo IL-6 KO mice do not upregulate this neurotrophin in DRG following nerve injury [136]. Experiments after injury of the hypoglossal nerve in mice also demonstrated a nerve regenerating role of IL-6 [137]. In contrast, in the facial nerve axotomy model no difference in neuronal survival was observed [104], whereas IL-6 was shown to be detrimental in a model of optic nerve injury [138]. 
CNS IL-6 is upregulated whenever neuroinflammation is expected, such as following CNS infection or injury or in a number of CNS diseases (Figures 2 and 3). Early studies demonstrated that IL-6 was expressed and produced in CNS during viral meningitis, in encephalitis mouse models, and in CSF of patients with acute viral infections [139]. IL-6 was also found to be upregulated in mouse experimental cerebral malaria (ECM) [140]. Moreover, IL-6 was highly found in CSF of patients with systemic lupus erithematosus (SLE) with CNS involvement [141] or in those in advanced stages of patients with human immunodeficiency virus [142] infections [143]. IL-6 levels in CSF were also significantly higher than plasma levels in patients who had suffered traumatic brain injury [144], and recently an IL-6 polymorphism $(-174 \mathrm{C} / \mathrm{G})$ has been associated with fatal outcome in patients with severe traumatic brain injury [145]. As expected, IL-6 is upregulated in several animal models of brain injury and shows a myriad of actions as suggested by studies in IL-6 KO mice which show a compromised inflammatory response, increased oxidative stress, impaired neuroglial activation, decreased lymphocyte recruitment and a slower rate of recovery and healing $[47,101,102,104,134,146-148]$. Of note, IL-6 is a critical cytokine controlling the transition from innate to acquired immunity, which is imperative for dealing properly with injured (and infected) CNS tissue, and where IL-6 trans-signalling is dramatically important [149]. In line with the results with IL-6 KO mice, GFAP-IL-6 mice (which overexpress IL-6 in the CNS) showed more rapid healing and recovery after traumatic brain injury because of extensive revascularization $[148,150]$. The transcriptomic analysis of IL-6KO mice versus WT mice [151] and that of GFAP-IL-6 mice [152] in a model of brain cortex cryoinjury revealed that IL- 6 modulates the expression of many genes involved in inflammation, apoptosis and oxidative stress among others.

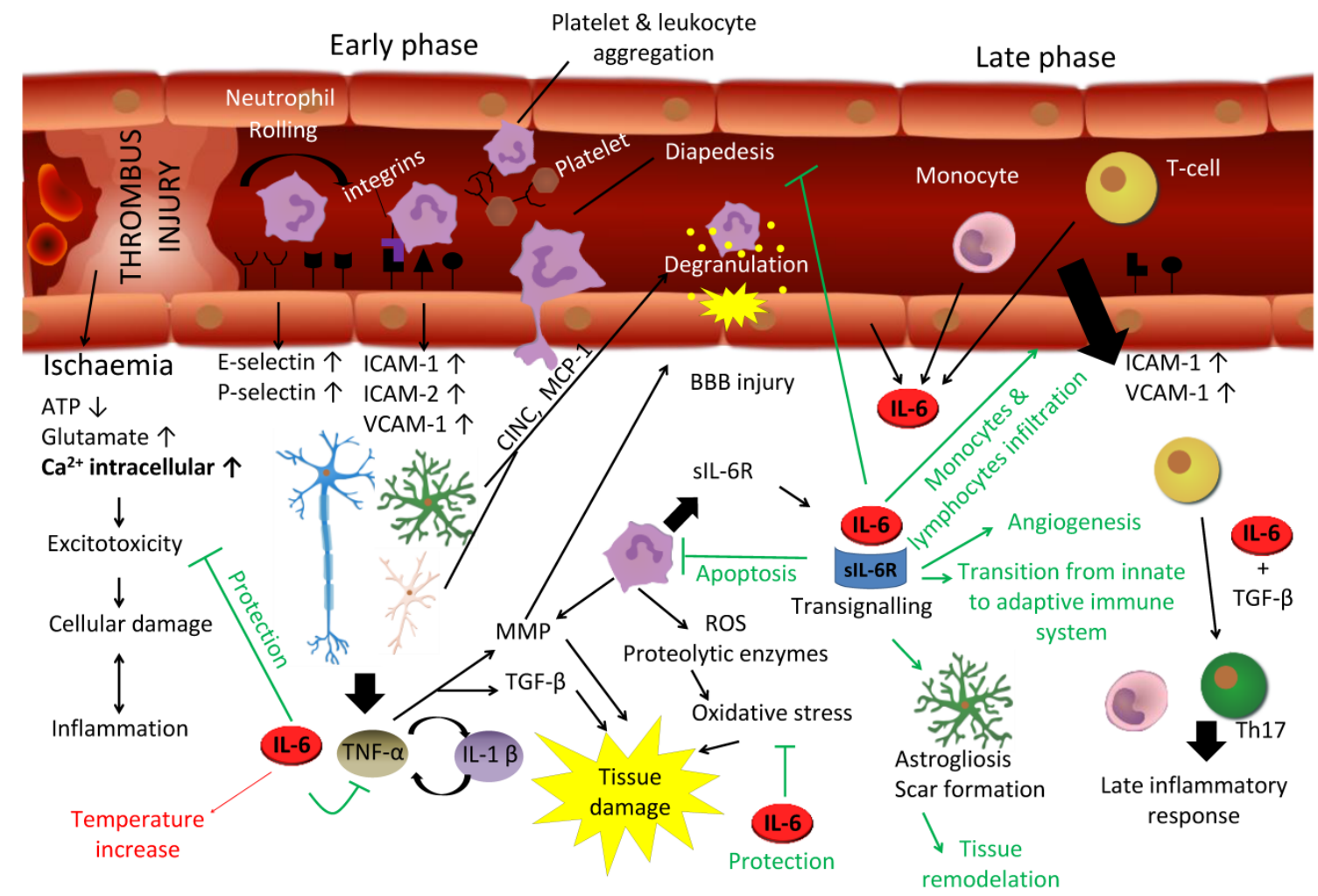

Figure 2. IL-6 has a major role in the response of the brain to injury. To some extent the response of the brain to trauma and stroke is similar. Stroke may be caused by an embolus/thrombus occlusion, an hemorrhage or a vasospasm, resulting in ischemia. Hypoxia initiates a biochemical cascade leading towards cell death, involving excitotoxicity, oxidative stress and apoptosis in which IL-6 has a protective effect. In the early response, neutrophils extravasate to nervous parenchyma involving a process of rolling, activation and transmigration due to an upregulation of $P$ and $E$-selectin, followed then by an upregulation of ICAM and VCAM. Neutrophils are a rich source of sIL-6R, and damaged resident cells produce IL-6, TNF- $\alpha$, IL-I $\beta$ and chemokines, enhancing leukocyte migration toward parenchyma. TNF- $\alpha$ and IL-I $\beta$ lead to neutrophil degranulation and tissue destruction by means of metalloproteinase (MMP) and TGF- $\beta$, while IL-6 inhibits TNF- $\alpha$ and neutrophils' diapedesis. Moreover, it induces apoptosis in neutrophils in a negative feedback loop. In the late phase of this response, IL- 6 orchestrates the transition between innate and adaptive immune response, not only inhibiting neutrophils but recruiting monocytes and T-cells for a late inflammatory response. Besides, it induces astrogliosis and angiogenesis needed for the tissue remodelation and recovering. On the other hand, IL-6 exhibits a detrimental effect for instance in relation with body temperature increase, critical in the patient outcome. If deregulated, chronic IL-6 may cause significant brain damage. 


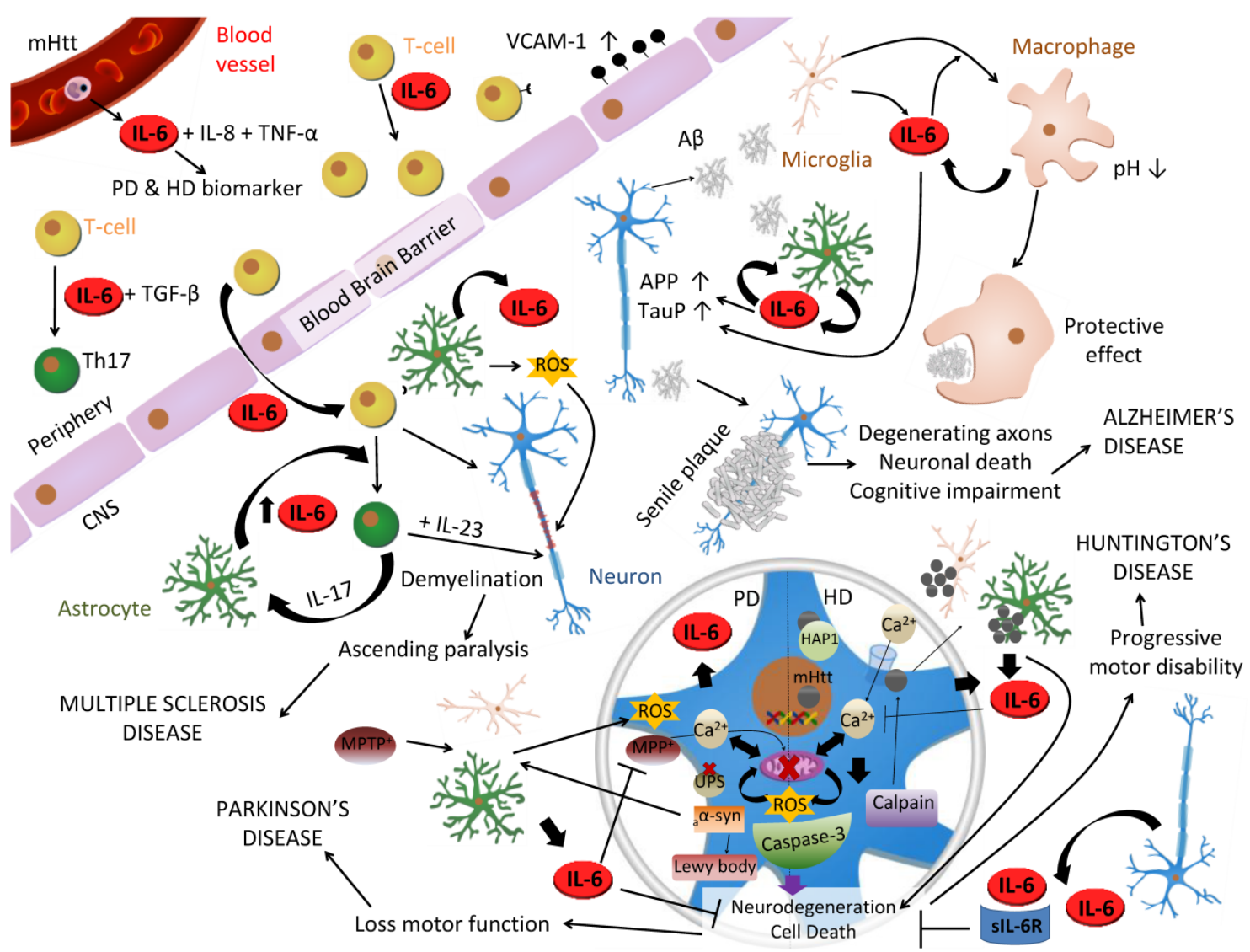

Figure 3. Role of IL-6 in CNS diseases. IL-6 has been related to many brain diseases. In Multiple Sclerosis (MS) IL-6 influences T-cell function inducing its proliferation and infiltration into CNS by upregulation of VCAM-I on the vascular endothelial cells. In the presence of TGF- $\beta$, it also induces T-cells differentiation into Th 17 cells, which secrete IL- 17 that stimulates IL-6 production in astrocytes in a positive feedback loop. Besides, T-cell direct contact induces production of IL-6, reactive oxygen species (ROS) and nitric oxide (NO) in astrocytes, which contribute to damaging myelin sheath and neurons that will led to ascending paralysis and, as long as IL-23 is present, the fully development of MS. In Alzheimer's disease, Amyloid- $\beta$ peptide (A $\beta$ ) produced by cleavage of amyloid precursor protein (APP), induces microgliosis, astrogliosis and triggers IL-6 production in both types of cells which upregulates APP and hyperphosphorylates tau in neurons. A $\beta$ is accumulated in the extracellular space forming senile plaques and inducing neuronal death. However, IL-6 can play a protective role differentiating microglia into phagocytic macrophages capable of degrading $A \beta$. Mutant Huntingtin (mHtt), associated with Huntington's disease [208], is a CAG expansion translated into intracellular polyglutamine inclusions which are toxic for the cell due to different pathways: increase in intracellular $\mathrm{Ca}^{2+}$ due to NMDA receptor binding, increase mitochondrial dysfunction with ROS production, and axonal transport disruption due to $\mathrm{mHtt} / \mathrm{HAPI}$ complexes. Elevated intracellular $\mathrm{Ca}^{2+}$ activates caspases and calpains, which cleave $\mathrm{mHtt}$ into toxic $\mathrm{N}$-terminal fragments triggering apoptosis in a positive feed-back loop. Furthermore, calpain causes autophagy inhibition resulting in high levels of mHtt in another positive feed-back loop. Moreover, microglia cells expressing $\mathrm{mHtt}$ also contribute to neuronal cells degeneration. Parkinson's disease (PD) is considered a synucleinopathy due to an abnormal intracellular accumulation of insoluble alpha-synuclein aggregations ( $\alpha$-syn) in the form of Lewy bodies in dopaminergic (DA) neurons due to a mutation, a toxic or an idiopathic form. Its etiopathogenesis remains unclear but, like HD, neuronal death is thought to be as a result of mitochondrial dysfunction with ROS production, an intracellular increase of $\mathrm{Ca}^{2+}$, oxidative stress and alterations in the ubiquitinproteasomal system (UPS) that become incapable to degrade ${ }_{a} \alpha$-syn, which triggers microglia to produce ROS. All together produce neurodegeneration and PD symptomatology. MPTP is metabolized into MPP+ by glial cells and primarily kills DA neurons, by interfering with mitochondrial metabolism, producing PD symptoms and being able to model a toxic PD in animals. In both diseases, IL-6 protects against $\mathrm{Ca}^{2+}$ and ROS excitotoxicity decreasing neuronal death.

Stroke patients also show significant elevations of CSF and serum IL-6 shortly after the ischemic event that correlate with brain infarct volume, and IL-6 haplotype affects both infarct size and IL-6 levels [153-157]. Ischemic brain injury involves inflammation, excitotoxicity, oxidative damage and apoptosis, and thus to some extent it is a similar scenario as that following traumatic brain injury. It is therefore not surprising that IL-6 may be an important factor orchestrating the responses elicited by stroke. In animal models of cerebral ischemia it has been a consistent finding an upregulation of IL-6, mostly in neurons but also in glial cells and vascular endothelium [158-161]. In line with the in vitro studies detailed above, neuronal IL-6 upregulation following cerebral ischemia is likely mediated by glutamate-induced neuronal depolarization [44, 162, 163]. Several of these studies clearly demonstrated a neuroprotective role of exogenously administered IL-6, as did experiments injecting anti-mouse IL-6 receptor monoclonal antibody [164] and with IL-6 KO mice provided body temperature is controlled [120, 165]. Controlling oxidative 
stress [166] and angiogenesis [165] are among the attributed functions of IL-6 during stroke. Epileptic seizures often involve excitotoxicity, and thus it was expected to find that patients suffering of epilepsy show increased CSF levels of IL-6 after seizures [167], and that well-known animal models of epilepsy such as the glutamate analog kainic acid (KA) upregulate CNS IL-6 [162]. IL-6 KO mice are more susceptible to various convulsant stimuli including several glutamate analogs and show clear signs of increased hippocampal damage [168-170]. Yet, this is a complex system, since intranasal administration of IL-6 to rats [171] and transgenic IL-6 expression in the brain [172] are proconvulsive. Also, some authors also claim a damaging role of IL-6 on neuron development in culture and on the response to NMDA [173] [174]. The reasons for such dual effects of IL-6 remain uncertain, but probably reflect that the context has a dramatic effect as often is the case with growth factors.

As a prototypical cytokine with roles in the control of inflammation, IL-6 is altered in CNS diseases where neuroinflammation may have a role. It is therefore not surprising that IL-6 expression is altered in the brains of Alzheimer's disease (AD) patients, being increased around amyloid plaques and in cerebrospinal fluid [175-179]. IL-6 stimulated the synthesis of the AD beta-amyloid precursor protein [180, 181], and, conversely, IL-6 is upregulated in cultured glial cells upon stimulation with the carboxy-terminal 105 amino acids of APP [182]. Moreover, IL-6 also enhances neuronal damage induced by beta-amyloid peptide in cultured rat cortical neurons [174]. Despite this detrimental role of IL-6 seen in vitro, in vivo studies with $\mathrm{AD}$ transgenic mouse models rather show a beneficial role of IL-6, in principle due to a massive gliosis which attenuated beta-amyloid peptide deposition and enhanced plaque clearance [183]. This is not unexpected as activated microglia can efficiently phagocytize beta-amyloid peptide and delay pathology course in transgenic models [184-186]. Astrocytes also may be involved in the clearance of beta-amyloid peptide [187], also by regulating microglial phagocytosis [188]. In humans, attempts to find important interactions between polymorphisms in specific alleles, such as the IL-6-174 G/C promoter allele, and genotype frequencies, are not conclusive [189-191]. The -572C/G polymorphism of IL-6 gene promoter region is another polymorphism that might be associated with AD [192].

Multiple sclerosis (MS) is an inflammatory demyelinating autoimmune disease of CNS mediated by CD4+T cells and soluble inflammatory mediators, in which IL-6 has an important role. While there is significant controversy on whether or not MS is corre- lated with either plasma or CSF IL-6, sIL6R and sgp130 levels [193-196], it has been demonstrated the presence of IL-6 in acute and chronic active plaques of MS patients, mainly associated with astrocytes rather than macrophages or mononuclear infiltrating cells [197]. Yet, the association of MS with IL-6 polymorphisms is again not conclusive [198, 199]. One of the most common animal model of MS is Experimental Autoimmune Encephalomyelitis (EAE) [200]. IL-6 is upregulated in CNS during EAE [201], and different approaches have demonstrated a major role of this cytokine. Thus, it was soon established that neutralization of IL-6 with antibodies led to a reduced disease [202], which later on was seen to be due to the suppression of the MOG-induced differentiation of naive T cells into Th17 and Th1 cells [203]. A seminal series of early studies demonstrated that IL-6 deficient mice were resistant to EAE [204-207], highlighting the essential role of this cytokine. Absence of infiltrating cells in the CNS, reduction of lymphocyte proliferation, change of the cytokine profile and failure to stimulate endothelial VCAM-1 were some of the reasons suggested to be responsible for resistance to EAE at the time. Trans-signaling is also crucial for EAE induction as its blockade with gp130-Fc fusion protein delayed the onset of adoptively transferred EAE compared to controls due to a reduction in VCAM-1 expression on spinal cord microvessels [208]. Since the discovery of two novel subsets of $\mathrm{T}$ helper cells, named Treg and Th17 cells, and its importance in MS, it has been shown that IL-6 has a major role in Th17 cell differentiation from naive $\mathrm{CD} 4{ }^{+} \mathrm{T}$ cells, particularly in the EAE model [203, 209, 210]. Th17 cells produce IL-17 (among other cytokines) which enhances IL-6 production by astrocytes, which in turn induces differentiation of Th17 cells in a positive feedback loop between IL-17 and IL-6 [53, 211]. Although EAE is considered a disease mostly induced peripherally, the fact is that the CNS local milieu may have dramatic effects. Thus, the GFAP-IL6 mouse model of chronic transgenic IL-6 expression [97] presents an atypical EAE due to a retargeting of the immune attack, with no signs of spinal cord damage while showing a prominent cerebellar damage [212]. The mechanisms responsible for these responses to IL-6 in the cerebellum are complex and likely to include an increased vascular activation, loss of integrity of the $\mathrm{BBB}$ and the induction of specific cytokines and chemokines.

Parkinson's disease (PD) is a degenerative disorder of the CNS with severe motor impairment, like shaking or rigidity among many others, due to the death of dopaminergic neurons in the substantia nigra. IL-6 is upregulated in PD [213, 214], and IL-6 
levels in the CSF of PD patients are elevated [215], although an inverse correlation between severity of PD and IL-6 levels is observed [216]. IL-6 KO mice show increased vulnerability to the MPTP, a molecule that is metabolized into the complex I inhibitor MPP+ by astrocytes and is a selective dopaminergic toxin [217], whereas IL-6 is capable of protecting rat dopaminergic neurons from the neurotoxicity of $\mathrm{MPP}^{+}$ [218]. Altogether, the results with these animal models of PD suggest that IL-6 could be exerting a neuroprotective role during PD.

Huntington's disease [208] is an inherited neurodegenerative disorder with both neurological and systemic abnormalities, characterized by abnormalities in the huntingtin gene. IL-6 expression is dramatically elevated in the striatum of HD patients, and in general these patients show clear signs of abnormal immune activation, IL- 6 being one of the cytokines affected and monocytes, macrophages and microglia (from both HD and mouse HD models) being overactive upon stimulation [219]. IL-6 is suggested to be neuroprotective as concluded from results with the quinolonic acid rat model of HD [220].

IL-6 has also been related to some psychiatric disorders. IL-6 is significantly elevated and highly correlated with major depression [221, 222]. Some studies have pointed out that IL-6 levels in CSF but not in plasma were increased in combat veterans with posttraumatic stress disorder (PTSD) in comparison with those of controls [223], and that IL-6 and/or sIL-6R levels in plasma but not sgp130 were significantly higher in PTSD patients respect to controls, and higher in PTSD patients with concurrent major depression than in PTSD patients or controls [224]. IL-6 has also been related with schizophrenia (SZ), a complex neurological disorder characterized by a breakdown of thought processes and by poor emotional responsiveness, commonly manifested with hallucinations, delusions, paranoid and mental deterioration $[225,226]$. Thus, a single maternal injection of IL-6 during pregnancy causes schizophrenia-like behavioral abnormalities in WT mice but not in IL-6 KO mice [227]. Finally, IL-6 has been found to be increased in the cerebellum of autistic brain [228] and has been suggested to mediate autism-like behaviors [229].

\section{Perspectives}

IL-6 is a major cytokine in the central nervous system. Many of its effects are caused by trans-signaling, while others are mediated by the membrane receptor; both can be essentially considered an integrated, unique system. The relevance of trans-signaling in vivo in a number of peripheral and
CNS diseases is widely recognized [111, 149, 230-234], and not surprisingly therapeutic approaches aiming to counteract IL-6 effects not only focus in IL-6 membrane receptor [235-238] but also in IL-6/sIL-6R complex [13, 239-241]. Likewise, sgp130 is also of an invaluable utility to specifically block diseases states in which trans-signaling responses exist [232, 234, 241], to the extent that the molecule has recently been structurally-optimized to better antagonize trans-signaling pathologic effects [242]. Still, we must keep in mind that IL- 6 has a role in the normal brain, and interfering with them may be a significant source of concern. Finally, we need to understand in vivo what the role(s) of IL-6 are to be due to specific cellular production of and response to IL-6; hopefully the production of floxed mice for IL-6 will help to answer these questions.

\section{Acknowledgements}

The authors apologize for not being able to reference all the many significant studies published in the field. The authors acknowledge the support of SAF2008-00435, SAF2011-23272, and by Instituto de Salud Carlos III and Ministerio de Ciencia e Innovación-Fondo Europeo de Desarrollo Regional (FEDER), ref. RETICS (REEM, RD07/0060/0002) to JH. AQ acknowledges the postdoc fellowship MICINN 2008-0671 and ME her PhD fellowship from UAB.

\section{Competing Interests}

The authors declare that no competing interest exists.

\section{References}

1. Hirano T, Taga T, Nakano N, Yasukawa K, Kashiwamura S, Shimizu K, et al. Purification to homogeneity and characterization of human B-cell differentiation factor (BCDF or BSFp-2). Proc Natl Acad Sci U S A. 1985; 82: 5490-4.

2. Yasukawa K, Hirano T, Watanabe Y, Muratani K, Matsuda T, Nakai S, et al. Structure and expression of human B cell stimulatory factor-2 (BSF-2/IL-6) gene. EMBO J. 1987; 6: 2939-45.

3. Yamasaki K, Taga T, Hirata Y, Yawata H, Kawanishi Y, Seed B, et al. Cloning and expression of the human interleukin-6 (BSF-2/IFN beta 2) receptor. Science. 1988; 241: 825-8.

4. Kishimoto T, Akira S, Narazaki M, Taga T. Interleukin-6 family of cytokines and gp130. Blood. 1995; 86: 1243-54.

5. Wang X, Lupardus P, Laporte SL, Garcia KC. Structural biology of shared cytokine receptors. Annu Rev Immunol. 2009; 27: 29-60.

6. Bazan JF. Haemopoietic receptors and helical cytokines. Immunol Today. 1990; 11: 350-4.

7. Bazan JF. Neuropoietic cytokines in the hematopoietic fold. Neuron. 1991; 7: 197-208.

8. Taga T, Kishimoto T. Cytokine receptors and signal transduction. FASEB J. 1992; 6: 3387-96.

9. Heinrich PC, Behrmann I, Haan S, Hermanns HM, Muller-Newen G, Schaper F. Principles of interleukin (IL)-6-type cytokine signalling and its regulation. Biochem J. 2003; 374: 1-20.

10. Bauer S, Kerr BJ, Patterson PH. The neuropoietic cytokine family in development, plasticity, disease and injury. Nat Rev Neurosci. 2007; 8: 221-32. 
11. Boulanger MJ, Chow DC, Brevnova EE, Garcia KC. Hexameric structure and assembly of the interleukin-6/IL-6 alpha-receptor/gp130 complex. Science. 2003; 300: 2101-4.

12. Saito M, Yoshida K, Hibi M, Taga T, Kishimoto T. Molecular cloning of a murine IL-6 receptor-associated signal transducer, gp130, and its regulated expression in vivo. J Immunol. 1992; 148: 4066-71.

13. Rose-John S, Waetzig GH, Scheller J, Grötzinger J, Seegert D. The IL-6/sIL-6R complex as a novel target for therapeutic approaches. Expert Opin Ther Targets. 2007; 11: 613-24.

14. Narazaki M, Yasukawa K, Saito T, Ohsugi Y, Fukui H, Koishihara Y, et al. Soluble forms of the interleukin-6 signal-transducing receptor component gp130 in human serum possessing a potential to inhibit signals through membrane-anchored gp130. Blood. 1993; 82: 1120-6.

15. Satoh T, Nakamura S, Taga T, Matsuda T, Hirano T, Kishimoto T, et al. Induction of neuronal differentiation in PC12 cells by B-cell stimulatory factor 2/interleukin 6. Mol Cell Biol. 1988; 8: 3546-9.

16. Nakafuku M, Satoh T, Kaziro Y. Differentiation factors, including nerve growth factor, fibroblast growth factor, and interleukin-6, induce an accumulation of an active Ras.GTP complex in rat pheochromocytoma PC12 cells. J Biol Chem. 1992; 267: 19448-54.

17. Cornfield LJ, Sills MA. High affinity interleukin- 6 binding sites in bovine hypothalamus. Eur J Pharmacol. 1991; 202: 113-5.

18. Schöbitz B, Voorhuis DA, De Kloet ER. Localization of interleukin 6 mRNA and interleukin 6 receptor mRNA in rat brain. Neurosci Lett. 1992; 136: 189-92.

19. Yan HQ, Banos MA, Herregodts P, Hooghe R, Hooghe-Peters EL. Expression of interleukin (IL)-1 beta, IL- 6 and their respective receptors in the normal rat brain and after injury. Eur J Immunol. 1992; 22: 2963-71.

20. Schöbitz B, de Kloet ER, Sutanto W, Holsboer F. Cellular localization of interleukin 6 mRNA and interleukin 6 receptor mRNA in rat brain. Eur J Neurosci. 1993; 5: 1426-35.

21. Gadient RA, Otten U. Differential expression of interleukin-6 (IL-6) and interleukin-6 receptor (IL-6R) mRNAs in rat hypothalamus. Neurosci Lett. 1993; 153: 13-6.

22. Gadient RA, Otten U. Identification of interleukin-6 (IL-6)-expressing neurons in the cerebellum and hippocampus of normal adult rats. Neurosci Lett. 1994; 182: 243-6.

23. Gadient RA, Otten U. Expression of interleukin-6 (IL-6) and interleukin-6 receptor (IL-6R) mRNAs in rat brain during postnatal development. Brain Res. 1994; 637: 10-4

24. Vallières L, Rivest S. Regulation of the genes encoding interleukin-6, its receptor, and gp130 in the rat brain in response to the immune activator lipopolysaccharide and the proinflammatory cytokine interleukin-1beta. J Neurochem. 1997; 69: 1668-83.

25. Sawada M, Itoh Y, Suzumura A, Marunouchi T. Expression of cytokine receptors in cultured neuronal and glial cells. Neurosci Lett. 1993; 160: 131-4.

26. Cannella B, Raine CS. Multiple sclerosis: cytokine receptors on oligodendrocytes predict innate regulation. Ann Neurol. 2004; 55: 46-57.

27. Gadient RA, Otten U. Postnatal expression of interleukin-6 (IL-6) and IL-6 receptor (IL-6R) mRNAs in rat sympathetic and sensory ganglia. Brain Res. 1996; 724: 41-6.

28. Gadient RA, Lachmund A, Unsicker K, Otten U. Expression of interleukin-6 (IL-6) and IL-6 receptor mRNAs in rat adrenal medulla. Neurosci Lett. 1995; 194: 17-20.

29. März P, Gadient RA, Otten U. Expression of interleukin-6 receptor (IL-6R) and gp130 mRNA in PC12 cells and sympathetic neurons: modulation by tumor necrosis factor alpha (TNF-alpha). Brain Res. 1996; 706: 71-9.

30. März P, Cheng JG, Gadient RA, Patterson PH, Stoyan T, Otten U, et al. Sympathetic neurons can produce and respond to interleukin 6. Proc Natl Acad Sci U S A. 1998; 95: 3251-6.

31. Jirik FR, Podor TJ, Hirano T, Kishimoto T, Loskutoff DJ, Carson DA, et al. Bacterial lipopolysaccharide and inflammatory mediators augment IL-6 secretion by human endothelial cells. J Immunol. 1989; 142: 144-7.

32. Modur V, Li Y, Zimmerman GA, Prescott SM, McIntyre TM. Retrograde inflammatory signaling from neutrophils to endothelial cells by soluble interleukin-6 receptor alpha. J Clin Invest. 1997; 100: 2752-6.

33. Reyes TM, Fabry Z, Coe CL. Brain endothelial cell production of a neuroprotective cytokine, interleukin- 6 , in response to noxious stimuli. Brain Res. 1999; 851: 215-20.

34. Frei K, Malipiero UV, Leist TP, Zinkernagel RM, Schwab ME, Fontana A. On the cellular surface and function of interleukin- 6 produced in the central nervous system in viral diseases. Eur J Immunol. 1989; 19: 689-94.

35. Righi M, Mori L, De Libero G, Sironi M, Biondi A, Mantovani A, et al. Monokine production by microglial cell clones. Eur J Immunol. 1989; 19: 1443-8.
36. Ringheim GE, Burgher KL, Heroux JA. Interleukin-6 mRNA expression by cortical neurons in culture: evidence for neuronal sources of interleukin-6 production in the brain. J Neuroimmunol. 1995; 63: 113-23.

37. Benveniste EN, Sparacio SM, Norris JG, Grenett HE, Fuller GM. Induction and regulation of interleukin- 6 gene expression in rat astrocytes. J Neuroimmunol. 1990; 30: 201-12.

38. Aloisi F, Carè A, Borsellino G, Gallo P, Rosa S, Bassani A, et al. Production of hemolymphopoietic cytokines (IL-6, IL-8, colony-stimulating factors) by normal human astrocytes in response to IL-1 beta and tumor necrosis factor-alpha. J Immunol. 1992; 149: 2358-66.

39. Sparacio SM, Zhang Y, Vilcek J, Benveniste EN. Cytokine regulation of interleukin-6 gene expression in astrocytes involves activation of an NF-kappa B-like nuclear protein. J Neuroimmunol. 1992; 39: 231-42.

40. Norris JG, Tang LP, Sparacio SM, Benveniste EN. Signal transduction pathways mediating astrocyte IL- 6 induction by IL-1 beta and tumor necrosis factor-alpha. J Immunol. 1994; 152: 841-50.

41. Cadman ED, Witte DG, Lee CM. Regulation of the release of interleukin-6 from human astrocytoma cells. J Neurochem. 1994; 63: 980-7.

42. Cadman ED, Naugles DD, Lee CM. cAMP is not involved in interleukin-1-induced interleukin-6 release from human astrocytoma cells. Neurosci Lett. 1994; 178: 251-4.

43. Sallmann S, Jüttler E, Prinz S, Petersen N, Knopf U, Weiser T, et al. Induction of interleukin-6 by depolarization of neurons. J Neurosci. 2000; 20: $8637-42$

44. Ali C, Nicole O, Docagne F, Lesne S, MacKenzie ET, Nouvelot A, et al. Ischemia-induced interleukin-6 as a potential endogenous neuroprotective cytokine against NMDA receptor-mediated excitotoxicity in the brain. J Cereb Blood Flow Metab 2000. 2000; 20: 956-66.

45. Sawada M, Suzumura A, Marunouchi T. TNF alpha induces IL-6 production by astrocytes but not by microglia. Brain Res. 1992; 583: 296-9.

46. Lee SC, Liu W, Dickson DW, Brosnan CF, Berman JW. Cytokine production by human fetal microglia and astrocytes. Differential induction by lipopolysaccharide and IL-1 beta. J Immunol. 1993; 150: 2659-67.

47. Woodroofe MN, Sarna GS, Wadhwa M, Hayes GM, Loughlin AJ, Tinker A, et al. Detection of interleukin- 1 and interleukin- 6 in adult rat brain, following mechanical injury, by in vivo microdialysis: evidence of a role for microglia in cytokine production. J Neuroimmunol 1991; 33: 227-36.

48. Sébire G, Emilie D, Wallon C, Héry C, Devergne O, Delfraissy JF, et al. In vitro production of IL-6, IL-1 beta, and tumor necrosis factor-alpha by human embryonic microglial and neural cells. J Immunol. 1993; 150: 1517-23.

49. Suzumura A, Sawada M, Marunouchi T. Selective induction of interleukin-6 in mouse microglia by granulocyte-macrophage colony-stimulating factor. Brain Res. 1996; 713: 192-8.

50. Hashioka S, Klegeris A, Monji A, Kato T, Sawada M, McGeer PL, et al. Antidepressants inhibit interferon-gamma-induced microglial production of IL-6 and nitric oxide. Exp Neurol. 2007; 206: 33-42.

51. Hariri RJ, Chang VA, Barie PS, Wang RS, Sharif SF, Ghajar JB. Traumatic injury induces interleukin- 6 production by human astrocytes. Brain Res. 1994; 636: 139-42.

52. Van Wagoner NJ, Oh JW, Repovic P, Benveniste EN. Interleukin-6 (IL-6) production by astrocytes: autocrine regulation by IL- 6 and the soluble IL-6 receptor. J Neurosci. 1999; 19: 5236-44.

53. Ma X, Reynolds SL, Baker BJ, Li X, Benveniste EN, Qin H. IL-17 enhancement of the IL- 6 signaling cascade in astrocytes. J Immunol. 2010; 184: 4898-906

54. Norris JG, Benveniste EN. Interleukin-6 production by astrocytes: induction by the neurotransmitter norepinephrine. J Neuroimmunol. 1993; 45: 137-45.

55. Maimone D, Cioni C, Rosa S, Macchia G, Aloisi F, Annunziata P. Norepinephrine and vasoactive intestinal peptide induce IL- 6 secretion by astrocytes: synergism with IL-1 beta and TNF alpha. J Neuroimmunol. 1993; 47: 73-81.

56. Gottschall PE, Tatsuno I, Arimura A. Regulation of interleukin-6 (IL-6) secretion in primary cultured rat astrocytes: synergism of interleukin-1 (IL-1) and pituitary adenylate cyclase activating polypeptide (PACAP). Brain Res. 1994; 637: 197-203.

57. Schettini G, Grimaldi M, Navarra P, Pozzoli G, Reichlin S, Preziosi P. Regulation of interleukin 6 production by cAMP-protein kinase-A pathway in rat cortical astrocytes. Pharmacol Res. 1994; 30: 13-24.

58. Grimaldi M, Pozzoli G, Navarra P, Preziosi P, Schettini G. Vasoactive intestinal peptide and forskolin stimulate interleukin 6 production by rat cortical astrocytes in culture via a cyclic AMP-dependent, prostaglandin-independent mechanism. J Neurochem. 1994; 63: 344-50.

59. Fiebich BL, Hüll M, Lieb K, Gyufko K, Berger M, Bauer J. Prostaglandin E2 induces interleukin-6 synthesis in human astrocytoma cells. J Neurochem. 1997; 68: 704-9. 
60. Fiebich BL, Hüll M, Lieb K, Schumann G, Berger M, Bauer J. Potential link between interleukin- 6 and arachidonic acid metabolism in Alzheimer's disease. J Neural Transm Suppl. 1998; 54: 268-78.

61. Fiebich BL, Lieb K, Berger M, Bauer J. Stimulation of the sphingomyelin pathway induces interleukin-6 gene expression in human astrocytoma cells. J Neuroimmunol. 1995; 63: 207-11.

62. Gitter BD, Regoli D, Howbert JJ, Glasebrook AL, Waters DC. Interleukin-6 secretion from human astrocytoma cells induced by substance P. J Neuroimmunol. 1994; 51: 101-8.

63. Lieb K, Schaller H, Bauer J, Berger M, Schulze-Osthoff K, Fiebich BL. Substance $P$ and histamine induce interleukin-6 expression in human astrocytoma cells by a mechanism involving protein kinase $\mathrm{C}$ and nuclear factor-IL-6. J Neurochem. 1998; 70: 1577-8315.

64. Schwaninger M, Sallmann S, Petersen N, Schneider A, Prinz S, Libermann TA, et al. Bradykinin induces interleukin- 6 expression in astrocytes through activation of nuclear factor-kappaB. J Neurochem. 1999; 73: 1461-6.

65. Fiebich BL, Biber K, Gyufko K, Berger M, Bauer J, van Calker D. Adenosine $A 2 b$ receptors mediate an increase in interleukin (IL)- 6 mRNA and IL-6 protein synthesis in human astroglioma cells. J Neurochem. 1996; 66: 1426-31.

66. Lieb K, Biersack L, Waschbisch A, Orlikowski S, Akundi RS, Candelario-Jalil E, et al. Serotonin via 5-HT7 receptors activates p38 mitogen-activated protein kinase and protein kinase $C$ epsilon resulting in interleukin-6 synthesis in human U373 MG astrocytoma cells. J Neurochem. 2005; 93: 549-59.

67. Schwaninger M, Petersen N, Prinz S, Sallmann S, Neher M, Spranger M. Adenosine-induced expression of interleukin- 6 in astrocytes through protein kinase A and NF-IL-6. Glia. 2000; 31: 51-8.

68. Suzumura A, Sawada M, Yamamoto H, Marunouchi T. Transforming growth factor-beta suppresses activation and proliferation of microglia in vitro. J Immunol. 1993; 151: 2150-8.

69. Benveniste EN, Kwon J, Chung WJ, Sampson J, Pandya K, Tang LP. Differential modulation of astrocyte cytokine gene expression by TGF-beta. J Immunol. 1994; 153: 5210-21.

70. Oh YJ, O'Malley KL. IL-6 increases choline acetyltransferase but not neuropeptide transcripts in sympathetic neurons. Neuroreport. 1994; 5: 937-40.

71. Fann MJ, Patterson PH. Neuropoietic cytokines and activin A differentially regulate the phenotype of cultured sympathetic neurons. Proc Natl Acad Sci U S A. 1994; 91: 43-7.

72. Zhong J, Dietzel ID, Wahle P, Kopf M, Heumann R. Sensory impairments and delayed regeneration of sensory axons in interleukin-6-deficient mice. J Neurosci. 1999; 19: 4305-13.

73. Cafferty WB, Gardiner NJ, Das P, Qiu J, McMahon SB, Thompson SW. Conditioning injury-induced spinal axon regeneration fails in interleukin-6 knock-out mice. J Neurosci. 2004; 24: 4432-43.

74. Ramer MS, Murphy PG, Richardson PM, Bisby MA. Spinal nerve lesion-induced mechanoallodynia and adrenergic sprouting in sensory ganglia are attenuated in interleukin-6 knockout mice. Pain. 1998; 78: 115-21.

75. Murphy PG, Ramer MS, Borthwick L, Gauldie J, Richardson PM, Bisby MA. Endogenous interleukin-6 contributes to hypersensitivity to cutaneous stimuli and changes in neuropeptides associated with chronic nerve constriction in mice. Eur J Neurosci. 1999; 11: 2243-53.

76. Hakkoum D, Stoppini L, Muller D. Interleukin-6 promotes sprouting and functional recovery in lesioned organotypic hippocampal slice cultures. J Neurochem. 2007; 100: 747-57.

77. Tancredi V, D'Antuono M, Cafè C, Giovedì S, Buè MC, D'Arcangelo G, et al. The inhibitory effects of interleukin- 6 on synaptic plasticity in the rat hippocampus are associated with an inhibition of mitogen-activated protein kinase ERK. J Neurochem. 2000; 75: 634-43.

78. Deverman BE, Patterson PH. Cytokines and CNS development. Cell. 2009; 64: 61-78.

79. Altman J, Das GD. Autoradiographic and histological evidence of postnatal hippocampal neurogenesis in rats. J Comp Neurol. 1965; 124: 319-35.

80. Ekdahl CT, Claasen JH, Bonde S, Kokaia Z, Lindvall O. Inflammation is detrimental for neurogenesis in adult brain. Proc Natl Acad Sci U S A. 2003; 100: 13632-7.

81. Whitney NP, Eidem TM, Peng H, Huang Y, Zheng JC. Inflammation mediates varying effects in neurogenesis: relevance to the pathogenesis of brain injury and neurodegenerative disorders. J Neurochem. 2009; 108: 1343-59.

82. Vallieres L, Campbell IL, Gage FH, Sawchenko PE. Reduced hippocampal neurogenesis in adult transgenic mice with chronic astrocytic production of interleukin-6. J Neurosci. 2002; 22: 486-92.
83. Monje ML, Toda H, Palmer TD. Inflammatory blockade restores adult hippocampal neurogenesis. Science. 2003; 302: 1760-5.

84. Nakanishi M, Niidome T, Matsuda S, Akaike A, Kihara T, Sugimoto H. Microglia-derived interleukin-6 and leukaemia inhibitory factor promote astrocytic differentiation of neural stem/progenitor cells. Eur J Neurosci. 2007; 25: 649-58.

85. Valerio A, Ferrario M, Dreano M, Garotta G, Spano P, Pizzi M. Soluble interleukin-6 (IL-6) receptor/IL-6 fusion protein enhances in vitro differentiation of purified rat oligodendroglial lineage cells. Mol Cell Neurosci. 2002; 21: 602-15.

86. Zhang PL, Izrael M, Ainbinder E, Ben-Simchon L, Chebath J, Revel M. Increased myelinating capacity of embryonic stem cell derived oligodendrocyte precursors after treatment by interleukin-6/soluble interleukin-6 receptor fusion protein. Mol Cell Neurosci 2006; 31: 387-98.

87. Islam $\mathrm{O}$, Gong $\mathrm{X}$, Rose-John $\mathrm{S}$, Heese K. Interleukin-6 and neural stem cells: more than gliogenesis. Mol Biol Cell. 2009; 20: 188-99.

88. Oh J, McCloskey MA, Blong CC, Bendickson L, Nilsen-Hamilton M, Sakaguchi DS. Astrocyte-derived interleukin-6 promotes specific neuronal differentiation of neural progenitor cells from adult hippocampus. J Neurosci Res. 2010; 88: 2798-809.

89. Benveniste EN, Whitaker JN, Gibbs DA, Sparacio SM, Butler JL. Human $B$ cell growth factor enhances proliferation and glial fibrillary acidic protein gene expression in rat astrocytes. Int Immunol. 1989; 1: 219-28.

90. Selmaj KW, Farooq M, Norton WT, Raine CS, Brosnan CF. Proliferation of astrocytes in vitro in response to cytokines. A primary role for tumor necrosis factor. J Immunol. 1990; 144: 129-35.

91. Levison SW, Jiang FJ, Stoltzfus OK, Ducceschi MH. IL-6-type cytokines enhance epidermal growth factor-stimulated astrocyte proliferation. Glia. 2000; 32: 328-37.

92. Streit WJ, Hurley SD, McGraw TS, Semple-Rowland SL. Comparative evaluation of cytokine profiles and reactive gliosis supports a critical role for interleukin-6 in neuron-glia signaling during regeneration. J Neurosci Res 2000; 61: 10-20.

93. März P, Heese K, Dimitriades-Schmutz B, Rose-John S, Otten U. Role of interleukin-6 and soluble IL-6 receptor in region-specific induction of astrocytic differentiation and neurotrophin expression. Glia. 1999; 26: 191-200.

94. Benveniste EN, Tang LP, Law RM. Differential regulation of astrocyte TNF-alpha expression by the cytokines TGF-beta, IL-6 and IL-10. Int J Dev Neurosci. 1995; 13: 341-9.

95. Meares GP, Ma X, Qin H, Benveniste EN. Regulation of CCL20 expression in astrocytes by IL-6 and IL-17. Glia. 2012; 60: 771-81.

96. Bolin LM, Zhaung A, Strychkarska-Orczyk I, Nelson E, Huang I, Malit $\mathrm{M}$, et al. Differential inflammatory activation of IL-6 (-/-) astrocytes. Cytokine 2005; 30: 47-55.

97. Campbell IL, Abraham CR, Masliah E, Kemper P, Inglis JD, Oldstone MBA, et al. Neurologic disease in transgenic mice by cerebral overexpression of interleukin 6. Proc Natl Acad Sci USA. 1993; 90: 10061-5.

98. Chiang C-S, Stalder A, Samimi A, Campbell IL. Reactive gliosis as a consequence of interleukin 6 expression in the brain: studies in transgenic mice. Dev Neurosci. 1994; 16: 212-21.

99. Fattori E, Lazzaro D, Musiani P, Modesti A, Alonzi T, Ciliberto G. IL-6 expression in neurons of transgenic mice causes reactive astrocytosis and increase in ramified microglial cells but no neuronal damage. Eur J Neurosci. 1995; 7: 2441-9.

100. Giralt M, Penkowa M, Hernández J, Molinero A, Carrasco J, Lago N, et al. Metallothionein-1+2 deficiency increases brain pathology in transgenic mice with astrocyte-targeted expression of interleukin 6 . Neurobiol Dis. 2002; 9: 319-38.

101. Klein MA, Möller JC, Jones LL, Bluethmann H, Kreutzberg GW, Raivich G. Impaired neuroglial activation in interleukin-6 deficient mice. Glia. 1997; 19: 227-33.

102. Penkowa M, Moos T, Carrasco J, Hadberg H, Molinero A, Bluethmann $\mathrm{H}$, et al. Strongly compromised inflammatory response to brain injury in interleukin-6-deficient mice. Glia. 1999; 25: 343-57.

103. Sugiura S, Lahav R, Han J, Kou SY, Banner LR, de Pablo F, et al. Leukaemia inhibitory factor is required for normal inflammatory responses to injury in the peripheral and central nervous systems in vivo and is chemotactic for macrophages in vitro. Eur J Neurosci. 2000; 12: 457-66.

104. Galiano M, Liu ZQ, Kalla R, Bohatschek M, Koppius A, Gschwendtner A, et al. Interleukin-6 (IL6) and cellular response to facial nerve injury: effects on lymphocyte recruitment, early microglial activation and axonal outgrowth in IL6-deficient mice. Eur J Neurosci. 2001; 14: 327-41.

105. Cardenas H, Bolin LM. Compromised reactive microgliosis in MPTP-lesioned IL-6 KO mice. Brain Res. 2003; 985: 89-97. 
106. Shrikant P, Weber E, Jilling T, Benveniste EN. Intercellular adhesion molecule-1 gene expression by glial cells. Differential mechanisms of inhibition by IL-10 and IL-6. J Immunol. 1995; 155: 1489-501.

107. Oh JW, Van Wagoner NJ, Rose-John S, Benveniste EN. Role of IL-6 and the soluble IL-6 receptor in inhibition of VCAM-1 gene expression. J Immunol. 1998; 161: 4992-9.

108. Romano M, Sironi M, Toniatti C, Polentarutti N, Fruscella P, Ghezzi P, et al. Role of IL- 6 and its soluble receptor in induction of chemokines and leukocyte recruitment. Immunity. 1997; 6: 315-25.

109. Pizzi M, Sarnico I, Boroni F, Benarese M, Dreano M, Garotta G, et al. Prevention of neuron and oligodendrocyte degeneration by interleukin- 6 (IL-6) and IL-6 receptor/IL-6 fusion protein in organotypic hippocampal slices. Mol Cell Neurosci. 2004; 25: 301-11.

110. Zhang PL, Levy AM, Ben-Simchon L, Haggiag S, Chebath J, Revel M. Induction of neuronal and myelin-related gene expression by IL-6-receptor/IL-6: a study on embryonic dorsal root ganglia cells and isolated Schwann cells. Exp Neurol. 2007; 208: 285-96.

111. Schöbitz B, Pezeshki G, Pohl T, Hemmann U, Heinrich PC, Holsboer F, et al. Soluble interleukin-6 (IL-6) receptor augments central effects of IL-6 in vivo. FASEB J. 1995; 9: 659-64.

112. Wallenius V, Wallenius K, Ahren B, Rudling M, Carlsten H, Dickson SL, et al. Interleukin-6-deficient mice develop mature-onset obesity. Nat Med. 2002; 8: 75-9.

113. Faldt J, Wernstedt I, Fitzgerald SM, Wallenius K, Bergstrom G, Jansson JO. Reduced exercise endurance in interleukin-6-deficient mice. Endocrinology. 2004; 145: 2680-6.

114. Wernstedt I, Edgley A, Berndtsson A, Faldt J, Bergstrom G, Wallenius V, et al. Reduced stress- and cold-induced increase in energy expenditure in interleukin-6-deficient mice. Am J Physiol Regul Integr Comp Physiol. 2006; 291: R551-R7.

115. Ruderman NB, Keller C, Richard AM, Saha AK, Luo Z, Xiang X, et al. Interleukin- 6 regulation of AMP-activated protein kinase. Potential role in the systemic response to exercise and prevention of the metabolic syndrome. Diabetes 2006; 55 Suppl 2: S48-S54.

116. Navarra P, Pozzoli G, Brunetti L, Ragazzoni E, Besser M, Grossman AB. Interleukin-1 beta and interleukin-6 specifically increase the release of prostaglandin E2 from rat hypothalamic explants in vitro. Neuroendocrinology. 1992; 56: 61-8.

117. Mastorakos G, Chrousos GP, Weber JS. Recombinant interleukin-6 activates the hypothalamic-pituitary-adrenal axis in humans. J Clin Endocrinol Metab. 1993; 77: 1690-4.

118. Klir JJ, Roth J, Szelényi Z, McClellan JL, Kluger MJ. Role of hypothalamic interleukin-6 and tumor necrosis factor-alpha in LPS fever in rat. Am J Physiol Cell Physiol. 1993; 265: R512-R7.

119. Chai Z, Gatti S, Toniatti C, Poli V, Bartfai T. Interleukin (IL)-6 gene expression in the central nervous system is necessary for fever response to lipopolysaccharide or IL-1 beta: a study on IL-6-deficient mice. J Exp Med. 1996; 183: 311-6.

120. Herrmann O, Tarabin V, Suzuki S, Attigah N, Coserea I, Schneider A, et al. Regulation of body temperature and neuroprotection by endogenous interleukin-6 in cerebral ischemia. J Cereb Blood Flow Metab. 2003; 23: 406-15.

121. Morrow JD, Opp MR. Sleep-wake behavior and responses of interleukin-6-deficient mice to sleep deprivation. Brain Behav Immun. 2005; 19: 28-39.

122. Armario A, Hernández J, Bluethmann H, Hidalgo J. IL-6 deficiency leads to increased emotionality in mice: evidence in transgenic mice carrying a null mutation for IL-6. J Neuroimmunol. 1998; 92: 160-9.

123. Butterweck V, Prinz S, Schwaninger M. The role of interleukin-6 in stress-induced hyperthermia and emotional behaviour in mice. Behav Brain Res. 2003; 144: 49-56.

124. Bluthé RM, Michaud B, Poli V, Dantzer R. Role of IL-6 in cytokine-induced sickness behavior: a study with IL-6 deficient mice. Physiol Behav. 2000; 70: 367-73.

125. Heyser CJ, Masliah E, Samimi A, Campbell IL, Gold LH. Progressive decline in avoidance learning paralleled by inflammatory neurodegeneration in transgenic mice expressing interleukin 6 in the brain. Proc Natl Acad Sci USA. 1997; 94: 1500-5.

126. Baier PC, May U, Scheller J, Rose-John S, Schiffelholz T. Impaired hippocampus-dependent and -independent learning in IL-6 deficient mice. Behav Brain Res. 2009; 200: 192-6.

127. Balschun D, Wetzel W, Del Rey A, Pitossi F, Schneider H, Zuschratter W, et al. Interleukin-6: a cytokine to forget. FASEB J. 2004; 18: 1788-90.

128. Hama T, Miyamoto M, Tsukui H, Nishio C, Hatanaka H. Interleukin-6 as a neurotrophic factor for promoting the survival of cultured basal forebrain cholinergic neurons from postnatal rats. Neurosci Lett. 1989; 104: 340-4.
129. Hama T, Kushima Y, Miyamoto M, Kubota M, Takei N, Hatanaka H. Interleukin-6 improves the survival of mesencephalic catecholaminergic and septal cholinergic neurons from postnatal, two-week-old rats in cultures. Neuroscience. 1991; 40: 445-52.

130. Mendonça Torres PM, de Araujo EG. Interleukin-6 increases the survival of retinal ganglion cells in vitro. J Neuroimmunol. 2001; 117: 43-50.

131. Thier M, März P, Otten U, Weis J, Rose-John S. Interleukin-6 (IL-6) and its soluble receptor support survival of sensory neurons. J Neurosci Res 1999; 55: 411-22.

132. D'Arcangelo G, Tancredi V, Onofri F, D'Antuono M, Giovedì S, Benfenati F. Interleukin-6 inhibits neurotransmitter release and the spread of excitation in the rat cerebral cortex. Eur J Neurosci. 2000; 12: 1241-52.

133. Murphy PG, Grondin J, Altares M, Richardson PM. Induction of interleukin-6 in axotomized sensory neurons. J Neurosci. 1995; 15: 5130-8.

134. Hans VH, Kossmann T, Lenzlinger PM, Probstmeier R, Imhof HG, Trentz O, et al. Experimental axonal injury triggers interleukin-6 mRNA, protein synthesis and release into cerebrospinal fluid. J Cereb Blood Flow Metab. 1999; 19: 184-94.

135. Murphy PG, Borthwick LS, Johnston RS, Kuchel G, Richardson PM. Nature of the retrograde signal from injured nerves that induces interleukin-6 mRNA in neurons. J Neurosci. 1999; 19: 3791-800.

136. Murphy PG, Borthwick LA, Altares M, Gauldie J, Kaplan D, Richardson PM. Reciprocal actions of interleukin- 6 and brain-derived neurotrophic factor on rat and mouse primary sensory neurons. Eur J Neurosci. 2000; 12: 1891-9.

137. Hirota H, Kiyama H, Kishimoto T, Taga T. Accelerated Nerve Regeneration in Mice by upregulated expression of interleukin (IL) 6 and IL-6 receptor after trauma. J Exp Med 1996; 183: 2627-34.

138. Fisher J, Mizrahi T, Schori H, Yoles E, Levkovitch-Verbin H, Haggiag S, et al. Increased post-traumatic survival of neurons in IL-6-knockout mice on a background of EAE susceptibility. J Neuroimmunol. 2001; 119: 1-9.

139. Frei K, Leist T, Meager A, Gallo P, Leppert D, Zinkernagel R, et al. Production of $\mathrm{B}$ cell stimulatory factor- 2 and interferon gamma in the central nervous system during viral meningitis and encephalitis. J Exp Med. 1988; 168: 449-53.

140. Grau GE, Frei K, Piguet PF, Fontana A, Heremans H, Billiau A, et al. Interleukin 6 production in experimental cerebral malaria: modulation by anticytokine antibodies and possible role in hypergammaglobulinemia. J Exp Med. 1990; 172: 1505-8.

141. Hirohata S, Miyamoto T. Elevated levels of interleukin-6 in cerebrospinal fluid from patients with systemic lupus erythematosus and central nervous system involvement. Arthritis Rheum. 1990; 33: 644-9.

142. Pagliusi SR, Schachner M, Seeburg PH, Shivers BD. The Adhesion Molecule on Glia (AMOG) Is Widely Expressed by Astrocytes in Developing and Adult Mouse Brain. Eur J Neurosci. 1990; 2: 471-80.

143. Laurenzi MA, Sidén A, Persson MA, Norkrans G, Hagberg L, Chiodi F. Cerebrospinal fluid interleukin-6 activity in HIV infection and inflammatory and noninflammatory diseases of the nervous system. Clin Immunol Immunopathol. 1990; 57: 233-41.

144. Kossmann T, Hans VH, Imhof HG, Stocker R, Grob P, Trentz O, et al. Intrathecal and serum interleukin- 6 and the acute-phase response in patients with severe traumatic brain injuries. Shock. 1995; 4: 311-7.

145. Dalla Libera AL, Regner A, de Paoli J, Centenaro L, Martins TT, Simon D. IL-6 polymorphism associated with fatal outcome in patients with severe traumatic brain injury. Brain Injury. 2011; 25: 365-9.

146. Taupin V, Toulmond S, Serrano A, Benavides J, Zavala F. Increase in IL-6, IL-1 and TNF levels in rat brain following traumatic lesion. Influence of pre- and post-traumatic treatment with Ro5 4864, a peripheral-type (p site) benzodiazepine ligand. J Neuroimmunol. 1993; 42: 177-85.

147. Penkowa M, Giralt M, Carrasco J, Hadberg H, Hidalgo J. Impaired inflammatory response and increased oxidative stress and neurodegeneration after brain injury in interleukin-6-deficient mice. Glia. 2000; 32: 271-85.

148. Swartz KR, Liu F, Sewell D, Schochet T, Campbell I, Sandor M, et al. Interleukin-6 promotes post-traumatic healing in the central nervous system. Brain Res. 2001; 896: 86-95.

149. Jones SA. Directing transition from innate to acquired immunity: defining a role for IL-6. J Immunol 2005; 175: 3463-8.

150. Penkowa M, Giralt M, Lago N, Camats J, Carrasco J, Hernández J, et al. Astrocyte-targeted expression of IL- 6 protects the CNS against a focal brain injury. Exp Neurol. 2003; 181: 130-48.

151. Poulsen CB, Penkowa M, Borup R, Nielsen FC, Caceres M, Quintana A, et al. Brain response to traumatic brain injury in wild-type and interleukin-6 knockout mice: a microarray analysis. J Neurochem. 2005; 92: 417-32.

152. Quintana A, Molinero A, Borup R, Nielsen FC, Campbell IL, Penkowa $\mathrm{M}$, et al. Effect of astrocyte-targeted production of IL- 6 on traumatic 
brain injury and its impact on the cortical transcriptome. Dev Neurobiol. 2008; 68: 195-208.

153. Beamer NB, Coull BM, Clark WM, Hazel JS, Silberger JR. Interleukin-6 and interleukin-1 receptor antagonist in acute stroke. Ann Neurol. 1995; 37: 800-5.

154. Tarkowski E, Rosengren L, Blomstrand C, Wikkelsö C, Jensen C, Ekholm S, et al. Early intrathecal production of interleukin-6 predicts the size of brain lesion in stroke. Stroke. 1995; 26: 1393-8.

155. Acalovschi D, Wiest T, Hartmann M, Farahmi M, Mansmann U, Auffarth GU, et al. Multiple levels of regulation of the interleukin-6 system in stroke. Stroke. 2003; 34: 1864-9.

156. Smith CJ, Emsley HC, Gavin CM, Georgiou RF, Vail A, Barberan EM, et al. Peak plasma interleukin- 6 and other peripheral markers of inflammation in the first week of ischaemic stroke correlate with brain infarct volume, stroke severity and long-term outcome. BMC Neurol. 2004; 4: 2.

157. Tso AR, Merino JG, Warach S. Interleukin-6 174G/C polymorphism and ischemic stroke: a systematic review. Stroke. 2007; 38: 3070-5.

158. Loddick SA, Turnbull AV, Rothwell NJ. Cerebral interleukin-6 is neuroprotective during permanent focal cerebral ischemia in the rat. J Cereb Blood Flow Metab. 1998; 18: 176-9.

159. Suzuki S, Tanaka K, Nogawa S, Nagata E, Ito D, Dembo T, et al. Temporal profile and cellular localization of interleukin-6 protein after focal cerebral ischemia in rats. J Cereb Blood Flow Metab. 1999; 19: 1256-62.

160. Orzyłowska O, Oderfeld-Nowak B, Zaremba M, Januszewski S, Mossakowski M. Prolonged and concomitant induction of astroglial immunoreactivity of interleukin-1beta and interleukin- 6 in the rat hippocampus after transient global ischemia. Neurosci Lett. 1999; 263: 72-6.

161. Suzuki S, Tanaka K, Suzuki N. Ambivalent aspects of interleukin-6 in cerebral ischemia: inflammatory versus neurotrophic aspects. J Cereb Blood Flow Metab. 2009; 29: 464-79.

162. Minami M, Kuraishi $Y$, Satoh M. Effects of kainic acid on messenger RNA levels of IL-1 beta, IL-6, TNF alpha and LIF in the rat brain. Biochem Biophys Res Commun. 1991; 176: 593-8.

163. Suzuki S, Tanaka K, Nogawa S, Dembo T, Kosakai A, Fukuuchi Y. Expression of interleukin- 6 is suppressed by inhibition of voltage-sensitive $\mathrm{Na}+/ \mathrm{Ca} 2+$ channels after cerebral ischemia. Neuroreport. 2000; 11: 2565-9.

164. Yamashita T, Sawamoto K, Suzuki S, Suzuki N, Adachi K, Kawase T, et al. Blockade of interleukin- 6 signaling aggravates ischemic cerebral damage in mice: possible involvement of Stat3 activation in the protection of neurons. J Neurochem. 2005; 94: 459-68.

165. Gertz K, Kronenberg G, Kälin RE, Baldinger T, Werner C, Balkaya M, et al. Essential role of interleukin-6 in post-stroke angiogenesis. Brain. 2012; in press.

166. Jung JE, Kim GS, Chan PH. Neuroprotection by interleukin-6 is mediated by signal transducer and activator of transcription 3 and antioxidative signaling in ischemic stroke. Stroke. 2011; 42: 3574-9.

167. Peltola J, Palmio J, Korhonen L, Suhonen J, Miettinen A, Hurme M, et al. Interleukin-6 and interleukin-1 receptor antagonist in cerebrospinal fluid from patients with recent tonic-clonic seizures. Epilepsy Res. 2000; 41: 205-11.

168. Penkowa M, Molinero A, Carrasco J, Hidalgo J. Interleukin-6 deficiency reduces the brain inflammatory response and increases oxidative stress and neurodegeneration after kainic acid-induced seizures. Neuroscience. 2001; 102: 805-18.

169. De Sarro G, Russo E, Ferreri G, Giuseppe B, Flocco MA, Di Paola ED, et al. Seizure susceptibility to various convulsant stimuli of knockout interleukin-6 mice. Pharmacol Biochem Behav. 2004; 77: 761-6.

170. De Luca G, Di Giorgio RM, Macaione S, Calpona PR, Costantino S, Di Paola ED, et al. Susceptibility to audiogenic seizure and neurotransmitter amino acid levels in different brain areas of IL-6-deficient mice. Pharmacol Biochem Behav 2004; 78: 75-81.

171. Kalueff AV, Lehtimaki KA, Ylinen A, Honkaniemi J, Peltola J. Intranasal administration of human IL-6 increases the severity of chemically induced seizures in rats. Neurosci Lett. 2004; 365: 106-10.

172. Samland H, Huitron-Resendiz S, Masliah E, Criado J, Henriksen SJ, Campbell IL. Profound increase in sensitivity to glutamatergic- but not cholinergic agonist-induced seizures in transgenic mice with astrocyte production of IL-6. J Neurosci Res. 2003; 73: 176-87.

173. Conroy SM, Nguyen V, Quina LA, Blakely-Gonzales P, Ur C, Netzeband JG, et al. Interleukin-6 produces neuronal loss in developing cerebellar granule neuron cultures. J Neuroimmunol. 2004; 155: 43-54.

174. Qiu Z, Gruol DL. Interleukin-6, beta-amyloid peptide and NMDA interactions in rat cortical neurons. J Neuroimmunol. 2003; 139: 51-7.

175. Bauer J, Strauss S, Schreiter-Gasser U, Ganter U, Schlegel P, Witt I, et al. Interleukin- 6 and alpha-2 macroglobulin indicate an acute-phase state in Alzheimer's disease cortices. FEBS Lett. 1991; 285: 111-4.
176. Strauss S, Bauer J, Ganter U, Jonas U, Berger M, Volk B. Detection of interleukin-6 and alpha 2-macroglobulin immunoreactivity in cortex and hippocampus of Alzheimer's disease patients. Lab Invest. 1992; 66: 223-30.

177. Wood JA, Wood PL, Ryan R, Graff-Radford NR, Pilapil C, Robitaille Y, et al. Cytokine indices in Alzheimer's temporal cortex: no changes in mature IL-1 beta or IL-1RA but increases in the associated acute phase proteins IL-6, alpha 2-macroglobulin and C-reactive protein. Brain Res. 1993; 629: 245-52.

178. Hüll M, Strauss S, Berger M, Volk B, Bauer J. The participation of interleukin-6, a stress-inducible cytokine, in the pathogenesis of Alzheimer's disease. Behav Brain Res. 1996; 78: 37-41.

179. Hampel H, Haslinger A, Scheloske M, Padberg F, Fischer P, Unger J, et al. Pattern of interleukin- 6 receptor complex immunoreactivity between cortical regions of rapid autopsy normal and Alzheimer's disease brain. Eur Arch Psychiatry Clin Neurosci. 2005; 255: 269-78.

180. Altstiel LD, Sperber K. Cytokines in Alzheimer's disease. Prog Neuropsychopharmacol Biol Psychiatry. 1991; 15: 481-95.

181. Ringheim GE, Szczepanik AM, Petko W, Burgher KL, Zhu SZ, Chao CC. Enhancement of beta-amyloid precursor protein transcription and expression by the soluble IL-6 receptor/IL-6 complex. Mol Brain Res. 1998; 55: 35- 44 .

182. Chong Y. Effect of a carboxy-terminal fragment of the Alzheimer's amyloid precursor protein on expression of proinflammatory cytokines in rat glial cells. Life Sci. 1997; 61: 2323-33.

183. Chakrabarty P, Jansen-West K, Beccard A, Ceballos-Diaz C, Levites Y, Verbeeck C, et al. Massive gliosis induced by interleukin-6 suppresses Abeta deposition in vivo: evidence against inflammation as a driving force for amyloid deposition. FASEB J. 2010; 24: 548-59.

184. Wyss-Coray T. Inflammation in Alzheimer disease: driving force, bystander or beneficial response? Nat Med. 2006; 12: 1005-15.

185. Simard AR, Soulet D, Gowing G, Julien JP, Rivest S. Bone marrow-derived microglia play a critical role in restricting senile plaque formation in Alzheimer's disease. Neuron. 2006; 49: 489-502.

186. Bolmont T, Haiss F, Eicke D, Radde R, Mathis CA, Klunk WE, et al. Dynamics of the microglial/amyloid interaction indicate a role in plaque maintenance. J Neurosci. 2008; 28: 4283-92.

187. Funato H, Yoshimura M, Yamazaki T, Saido TC, Ito Y, Yokofujita J, et al. Astrocytes containing amyloid beta-protein (Abeta)-positive granules are associated with Abeta40-positive diffuse plaques in the aged human brain. Am J Pathol. 1998; 152: 983-92.

188. DeWitt DA, Perry G, Cohen M, Doller C, Silver J. Astrocytes regulate microglial phagocytosis of senile plaque cores of Alzheimer's disease. Exp Neurol. 1998; 149: 329-40.

189. Papassotiropoulos A, Bagli M, Jessen F, Bayer TA, Maier W, Rao ML, et al. A genetic variation of the inflammatory cytokine interleukin-6 delays the initial onset and reduces the risk for sporadic Alzheimer's disease. Ann Neurol. 1999; 45: 666-8.

190. Capurso C, Solfrizzi V, D'Introno A, Colacicco AM, Capurso SA, Capurso A, et al. Interleukin 6-174 G/C promoter gene polymorphism and sporadic Alzheimer's disease: geographic allele and genotype variations in Europe. Exp Gerontol. 2004; 39: 1567-73.

191. Han XM, Wang CH, Sima X, Liu SY. Interleukin-6 -174G/C polymorphism and the risk of Alzheimer's disease in Caucasians: a meta-analysis. Neurosci Lett 2011; 504: 4-8.

192. He MX, Yang WL, Zhang MM, Lian YJ, Hua HY, Zeng JS, et al. Association between interleukin-6 gene promoter $-572 \mathrm{C} / \mathrm{G}$ polymorphism and the risk of sporadic Alzheimer's disease. Neurol Sci. 2010; 31: 165-8.

193. Frei K, Fredrikson S, Fontana A, Link H. Interleukin-6 is elevated in plasma in multiple sclerosis. J Neuroimmunol. 1991; 31: 147-53.

194. Padberg F, Feneberg W, Schmidt S, Schwarz MJ, Körschenhausen D, Greenberg BD, et al. CSF and serum levels of soluble interleukin-6 receptors (sIL-6R and sgp130), but not of interleukin-6 are altered in multiple sclerosis. J Neuroimmunol. 1999; 99: 218-23.

195. Vladić A, Horvat G, Vukadin S, Sucić Z, Simaga S. Cerebrospinal fluid and serum protein levels of tumour necrosis factor-alpha (TNF-alpha) interleukin-6 (IL-6) and soluble interleukin-6 receptor (sIL-6R gp80) in multiple sclerosis patients. Cytokine. 2002; 20: 86-9.

196. Malmeström C, Andersson BA, Haghighi S, Lycke J. IL-6 and CCL2 levels in CSF are associated with the clinical course of MS: implications for their possible immunopathogenic roles. J Neuroimmunol. 2006; 175: 176-82.

197. Maimone D, Guazzi GC, Annunziata P. IL-6 detection in multiple sclerosis brain. J Neurol Sci. 1997; 146: 59-65.

198. Fedetz M, Matesanz F, Pascual M, Martín J, Fernández O, Guerrero M, et al. The $-174 /-597$ promoter polymorphisms in the interleukin-6 gene are 
not associated with susceptibility to multiple sclerosis. J Neurol Sci. 2001; 190: 69-72.

199. Schmidt S, Papassotiropoulos A, Sotgiu S, Kölsch H, Arru G, Fois ML, et al. Investigation of a genetic variation of a variable number tandem repeat polymorphism of interleukin- 6 gene in patients with multiple sclerosis. J Neurol Sci. 2003; 250: 607-11.

200. Baxter AG. The origin and application of experimental autoimmune encephalomyelitis. Nat Rev Immunol. 2007; 7: 904-12.

201. Gijbels K, Van Damme J, Proost P, Put W, Carton H, Billiau A. Interleukin 6 production in the central nervous system during experimental autoimmune encephalomyelitis. Eur J Immunol. 1990; 20: 233-5.

202. Gijbels K, Brocke S, Abrams JS, Steinman L. Administration of neutralizing antibodies to interleukin-6 (IL-6) reduces experimental autoimmune encephalomyelitis and is associated with elevated levels of IL-6 bioactivity in central nervous system and circulation. Mol Med. 1995; 1: 795-805.

203. Serada S, Fujimoto M, Mihara M, Koike N, Ohsugi Y, Nomura S, et al. IL-6 blockade inhibits the induction of myelin antigen-specific Th17 cells and Th1 cells in experimental autoimmune encephalomyelitis. Proc Natl Acad Sci U S A. 2008; 105: 9041-6.

204. Okuda Y, Sakoda S, Bernard CC, Fujimura H, Saeki Y, Kishimoto T, et al. IL-6-deficient mice are resistant to the induction of experimental autoimmune encephalomyelitis provoked by myelin oligodendrocyte glycoprotein. Int Immunol. 1998; 10: 703-8.

205. Mendel I, Katz A, Kozak N, Ben-Nun A, Revel M. Interleukin-6 functions in autoimmune encephalomyelitis: a study in gene-targeted mice. Eur J Immunol. 1998; 28: 1727-37.

206. Eugster H-P, Frei K, Kopf M, Lassmann H, Fontana A. IL-6 deficient mice resist myelin oligodendrocyte glycoprotein-induced autoimmune encephalomyelitis. Eur J Immunol. 1998; 28: 2178-87.

207. Samoilova EB, Horton JL, Hilliard B, Liu TS, Chen Y. IL-6-deficient mice are resistant to experimental autoimmune encephalomyelitis: roles of IL- 6 in the activation and differentiation of autoreactive T cells. J Immunol. 1998; 161: 6480-6.

208. Linker RA, Lühder F, Kallen KJ, Lee DH, Engelhardt B, Rose-John S, et al. IL-6 transsignalling modulates the early effector phase of EAE and targets the blood-brain barrier. J Neuroimmunol. 2008; 205: 64-72.

209. Bettelli E, Carrier Y, Gao W, Korn T, Strom TB, Oukka M, et al. Reciprocal developmental pathways for the generation of pathogenic effector TH17 and regulatory T cells. Nature. 2006; 441: 235-8.

210. Murphy AC, Lalor SJ, Lynch MA, Mills KH. Infiltration of Th1 and Th17 cells and activation of microglia in the CNS during the course of experimental autoimmune encephalomyelitis. Brain Behav Immun. 2010; 24: 641-51.

211. Ogura H, Murakami M, Okuyama Y, Tsuruoka M, Kitabayashi C, Kanamoto $\mathrm{M}$, et al. Interleukin-17 promotes autoimmunity by triggering a positive-feedback loop via interleukin-6 induction. Immunity. 2008; 29: 628-36.

212. Quintana A, Müller M, Frausto RF, Ramos R, Getts DR, Sanz E, et al. Site-specific production of IL-6 in the central nervous system retargets and enhances the inflammatory response in experimental autoimmune encephalomyelitis. J Immunol. 2009; 183: 2079-88.

213. Mogi M, Harada M, Kondo T, Riederer P, Inagaki H, Minami M, et al. Interleukin-1 beta, interleukin-6, epidermal growth factor and transforming growth factor-alpha are elevated in the brain from parkinsonian patients. Neurosci Lett 1994; 180: 147-50.

214. Nagatsu T, Sawada M. Biochemistry of postmortem brains in Parkinson's disease: historical overview and future prospects. J Neural Transm Suppl 2007; 72: 113-20.

215. Mogi M, Harada M, Narabayashi H, Inagaki H, Minami M, Nagatsu T. Interleukin (IL)-1 beta, IL-2, IL-4, IL-6 and transforming growth factor-alpha levels are elevated in ventricular cerebrospinal fluid in juvenile parkinsonism and Parkinson's disease. Neurosci Lett 1996; 211: 13-6.

216. Müller T, Blum-Degen D, Przuntek H, Kuhn W. Interleukin-6 levels in cerebrospinal fluid inversely correlate to severity of Parkinson's disease. Acta Neurol Scand. 1998; 98: 142-4.

217. Bolin LM, Strycharska-Orczyk I, Murray R, Langston JW, Di Monte D. Increased vulnerability of dopaminergic neurons in MPTP-lesioned interleukin-6 deficient mice. J Neurochem. 2002; 83: 167-75.

218. Akaneya Y, Takahashi M, Hatanaka H. Interleukin-1 beta enhances survival and interleukin- 6 protects against MPP+ neurotoxicity in cultures of fetal rat dopaminergic neurons. Exp Neurol. 1995; 136: 44-52.

219. Björkqvist M, Wild EJ, Thiele J, Silvestroni A, Andre R, Lahiri N, et al. A novel pathogenic pathway of immune activation detectable before clinical onset in Huntington's disease. J Exp Med. 2008; 205: 1869-77.

220. Bensadoun JC, de Almeida LP, Dréano M, Aebischer P, Déglon N. Neuroprotective effect of interleukin-6 and IL6/IL6R chimera in the quino- linic acid rat model of Huntington's syndrome. Eur J Neurosci. 2001; 14: 1753-61.

221. Maes M, Scharpé S, Meltzer HY, Bosmans E, Suy E, Calabrese J, et al. Relationships between interleukin- 6 activity, acute phase proteins, and function of the hypothalamic-pituitary-adrenal axis in severe depression. Psychiatry Res. 1993; 49: 11-27.

222. Dowlati Y, Herrmann N, Swardfager W, Liu H, Sham L, Reim EK, et al. A meta-analysis of cytokines in major depression. Biol Psychiatry. 2010; 67: 446-57.

223. Baker DG, Ekhator NN, Kasckow JW, Hill KK, Zoumakis E, Dashevsky BA, et al. Plasma and cerebrospinal fluid interleukin- 6 concentrations in posttraumatic stress disorder. Neuroimmunomodulation. 2001; 9: 209-17.

224. Maes M, Lin AH, Delmeire L, Van Gastel A, Kenis G, De Jongh R, et al. Elevated serum interleukin-6 (IL-6) and IL-6 receptor concentrations in posttraumatic stress disorder following accidental man-made traumatic events. Biol Psychiatry. 1999; 45: 833-9.

225. Potvin S, Stip E, Sepehry AA, Gendron A, Bah R, Kouassi E. Inflammatory cytokine alterations in schizophrenia: a systematic quantitative review. Biol Psychiatry. 2008; 63: 801-8.

226. Patterson PH. Immune involvement in schizophrenia and autism: etiology, pathology and animal models. Behav Brain Res 2009; 204: 313-21.

227. Smith SE, Li J, Garbett K, Mirnics K, Patterson PH. Maternal immune activation alters fetal brain development through interleukin-6. J Neurosci. 2007; 27: 10695-702.

228. Wei H, Zou H, Sheikh AM, Malik M, Dobkin C, Brown WT, et al. IL-6 is increased in the cerebellum of autistic brain and alters neural cell adhesion, migration and synaptic formation. J Neuroinflammation. 2011; 8: 52.

229. Wei H, Chadman KK, McCloskey DP, Sheikh AM, Malik M, Brown WT, et al. Brain IL-6 elevation causes neuronal circuitry imbalances and mediates autism-like behaviors. Biochim Biophys Acta. 2012; 1822: 831-42.

230. März P, Otten U, Rose-John S. Neural activities of IL-6-type cytokines often depend on soluble cytokine receptors. Eur J Neurosci. 1999; 11: 2995-3004.

231. Hurst SM, Wilkinson TS, McLoughlin RM, Jones S, Horiuchi S, Yamamoto N, et al. Il-6 and its soluble receptor orchestrate a temporal switch in the pattern of leukocyte recruitment seen during acute inflammation. Immunity. 2001; 14: 705-14

232. Nowell MA, Richards PJ, Horiuchi S, Yamamoto N, Rose-John S, Topley $\mathrm{N}$, et al. Soluble IL-6 receptor governs IL-6 activity in experimental arthritis: blockade of arthritis severity by soluble glycoprotein 130 . J Immunol. 2003; 171: 3202-9.

233. Jones SA, Horiuchi S, Topley N, Yamamoto N, Fuller GM. The soluble interleukin 6 receptor: mechanisms of production and implications in disease. Faseb J. 2001; 15: 43-58.

234. Lemmers A, Gustot T, Durnez A, Evrard S, Moreno C, Quertinmont E, et al. An inhibitor of interleukin-6 trans-signalling, sgp130, contributes to impaired acute phase response in human chronic liver disease. Clin Exp Immunol. 2009; 156: 518-27.

235. Ding C, Jones G. Technology evaluation: MRA, Chugai. Curr Opin Mol Ther. 2003; 5: 64-9.

236. Ito H. Anti-interleukin-6 therapy for Crohn's disease. Curr Pharm Des. 2003; 9: 295-305.

237. Ding C, Cicuttini F, Li J, Jones G. Targeting IL-6 in the treatment of inflammatory and autoimmune diseases. Expert Opin Investig Drugs. 2009; 18: 1457-66.

238. Tanaka T, Narazaki M, Kishimoto T. Therapeutic targeting of the interleukin-6 receptor. Annu Rev Pharmacol Toxicol. 2012; 52: 199-219.

239. Atreya R, Mudter J, Finotto S, Müllberg J, Jostock T, Wirtz S, et al. Blockade of interleukin 6 trans signaling suppresses T-cell resistance against apoptosis in chronic intestinal inflammation: evidence in crohn disease and experimental colitis in vivo. Nat Med. 2000; 6: 583-8.

240. Nowell MA, Williams AS, Carty SA, Scheller J, Hayes AJ, Jones GW, et al. Therapeutic targeting of IL-6 trans signaling counteracts STAT3 control of experimental inflammatory arthritis. J Immunol. 2009; 182: 613-22.

241. Jones SA, Scheller J, Rose-John S. Therapeutic strategies for the clinical blockade of IL-6/gp130 signaling. J Clin Invest. 2011; 121: 3375-83.

242. Tenhumberg S, Waetzig GH, Chalaris A, Rabe B, Seegert D, Scheller J, et al. Structure-guided optimization of the interleukin- 6 trans-signaling antagonist sgp130. J Biol Chem. 2008; 283: 27200-7. 